\title{
A QUESTÃO AMBIENTAL, O MINISTÉRIO PÚBLICO E AS AÇÕES CIVIS PÜBLICAS
}

Gustavo José Mendes Tepedino *

SUMARIO: I. Introducho: importancia da questäo ambiental. O meio ambiente como volor social e existucial a despatrimoniabaçäo dos institutos de dreito privado. 2. O Ministzrio Publico como agente de efetivaço da tebua axiologica constitucional. Afmcão promocional do Ministerio Publico 3 . A acto civil pablica como instrumento privilegiado para o extcicio coletivo da cidadania. Aspectos controvertidos: a o objeto da acao civl publica; b) a defesa dos interesses irdividuats honogenes pelo Minsterio Publico, c) o litisconsortio entre as Ministerios Publicos da Uniaro do Detrito Federnl e dos Estados; d) o local do dano e a competencia funcionatterritorial para a propositura da aça. A Sumula n." 183 do ST. 4. Bibliografta.

SUMMARY: 1. Introduction: importance of the ambient question. The enviroment as socid and existencial value: the despatrimonial of the instidutes of private law. 2. The Public prosecuion service as effective agent of the constitutional axiological board. The pronocional funtion of the Public Prosecution service. 3. The public civil action as priviteged instrument for the collective excrise of the citizenship. Controverted aspects: the object of the public civil action; b) the defense of the homogeneous individual interests for the Public prosecution service; c) the joinder of pantics cnters the Public Ministries of the Union, the Federal District and the States, d) the place of the damage and the functionary-territorial ability for the bringing suit of the action. The Abridgemen n. ${ }^{\circ} 183$ of STJ. 4. Bibliography.

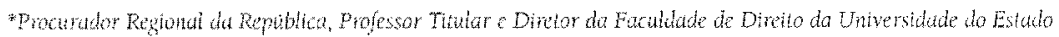

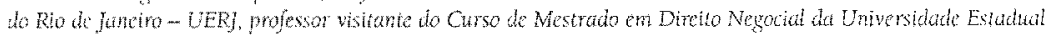
ute Lonthind
} 
ÜBERSICHT: 1- Einführung: Bedeutung der Umweltfrage. Die Umwelt als gesellschaflicher und existenzieller Wert: die Bedeutungsmindenng der Institutionen des Privatrechts. 2- Die Stadsanwaltschdt als Vertreter der von der Verfassung gesetzten Werte. Deren Förderung als Augabe der Statsanwalschaft. Die ofenthche Zivilhage als worangiges Mittel zu gemeinsonen Ausübung des Büremeches. Streitige Gesichtspunkte: a) der Gegensiand der offentichen Ziwhlage; b) de Wahmehmung der gleichartigen Indwidualneressen durch de Startanwallschaft; $c$ ) die Streitgenossenschaft zwischen den Statsamwalschaften des Bundes, des Bundesbezirs und der Lander; 0 der Or des Schadenseintrits und die sachiche und ortliche Zustandigheit für die Klageenhebung. Der Leitsatz 183 des STJ. 4. Bibliographie.

RESUMO: O presente estudo tem como objetivo abordar a necessidade de se tomar compativel o instrumental técnico-juridico com a proteça do interesse ambiental que se apresenta, essencidmente, em sua dimensäo coletiva extrapatrimonial. Tal necessidade advinda da analise da aça civil publica e a atuaçáo do Ministério Phblico como formas de tutela previstas, mas ainda controvertidas.

ABSTRACT: The present study has as objective to approach the necessity of becoming compatible the technician-Legal instrument with the protection of the ambient interest wich presents, itself essentially, in its collective and despatrimonial dimension. Such happened necessity of the analysis of the public civil action and the performance of the Public prosecution service as foresen forms of guardianship, but still controverted.

ZUSAMMENFASSUNG: Die Arbeit will auf die Notwendigheit hinweisen, das juristische Instrumentarium mit dem Inwelschutz in ubereinstimmung zu bringen, der sich wesentlich in seiner kollektiven und ausserhalb des Eigentumsrechts stehenden Bedeutung darstell. Diese Notwendigkeit zeigt sich an der Analyse der offentlichen Zivillage und der Tatigheit der Staatsanwalschalt als erwarteter, aber noch unstrittener Formen des Umweltschutzes.

PALAVRAS-CHAVE: Ministêrio Publico. Questáo ambiental. Acóo civil publica. Meio ambiente. 
KEY-WORDS: Prosecuting counsel. Environmental question. Civil action public. Environment

SCHLÜSSELWÖRTER: Staatsanwaltschaft. Umweltfrage. Öffentliche Zivilklage. Umwelt.

\section{INTRODUÇÃO: Importância da questão ambiental. $O$ meio ambiente como valor social e existencial: $a$ despatrimonialização dos institutos de direito privado}

$H$

á mais de vinte anos, quando a questão ambiental entrou na pauta da academia, impondo-se, pouco a pouco, como prioritária para o jurista europeu, o Professor Stefano Rodotà, durante um importante congresso sobre a até então desconhecida categoria dos interesses difusos, advertia para o fato de que a tutela do meio ambiente suscitaria um "risveglio complessivo della magistratura"... Mais do que um novo ramo do direito, o direito ambiental representava, com efeito, uma ruptura com o instrumental térico e processual do passado, chegando a alterar até mesmo o papel desempenhado pelos profissionais do direito e, em particular, pelo magistrado.

$\mathrm{Na}$ experiência brasileira, onde a questão ambiental encontra-se na ordem do dia, percebem-se nitidamente as dificuldades dos operadores diante de uma temática que exige a superação da ótica patrimonial e individualista que caracterizou, na esteira do paradigma do direito subjetivo e da propriedade, as técnicas do direito substantivo e do processo civil. Com efeito, a patrimonialidade e o individualismo - expresso quer no pressuposto

${ }^{1}$ Le azioni civilistiche, in Le azioni a tutela degli interessi diflusi, Atti del convegno di sludio (Pavia, 11-12 gitugno 1974), Padova, Codam, 1976, p.90. 
subjetivo para a responsabilidade civil, quer no âmbito processual, como referência à individualização dos interesses - serviam, no passado, de critérios seguros para a solução de controvérsias privadas, informando o vasto leque de questöes atinentes à violação de direitos, à reparação de danos, à liquidação de obrigaçóes, à legitimidade processual, aos eleitos da coisa julgada e assim por diante.

A introdução, no cenário juridico, da matéria ambiental, coloca em crise toda a consolidada dogmática, exigindo a formulaçăo de novas categorias e a releitura da normativa vigente, de sorte a tomar compativel o instrumental técnico-jurídico com a proteção do interesse ambiental que se apresenta, essencialmente, em sua dimensão coletiva e extrapatrimonial, exigindo tutela jurídica, mesmo quando näo se tenha presente um direito subjetivo previamente tipificado pelo ordenamento.

Com efeito, segundo a dicção do art. 225 da Constituição da República, "todos têm direito ao meio ambiente ecologicamente equilibrado, bem de uso comum do povo essencial à sadia qualidade de vida, impondose ao Poder Público e a coletividade o dever de defendê-lo e preservá-lo para as presentes e futuras geraçóes". O preceito é seguido por seis parágrafos que atribuem ao Poder Público deveres especificos para lhe dar efetividade, sendo certo que o art. 225 deva ser lido em consonancia com os princípios fundamentais definidos nos ants. $1^{\circ}$ a $4^{\circ}$, que fazem da tutela ao melo ambiente um instrumento de realizaçăo da cidadania e da dignidade da pessoa humana ${ }^{2}$.

Considerando-se como meio ambiente "a interação do conjunto de elementos naturais, artificiais e culturais que propiciam o desenvolvimento equilibrado da vida humana" sublinhou-se, em doutrina, a necessidade de incluir na tutela constitucional todos os elementos que "de alguma forma contribuam para a existência, a manutenção e o aprimoramento da vida e de sua qualidade. Nesse campo inclui-se, sem dúvida, o patrimônio cultural,

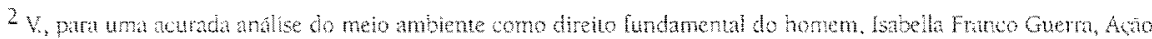

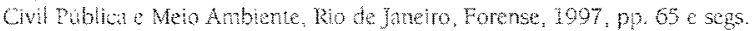

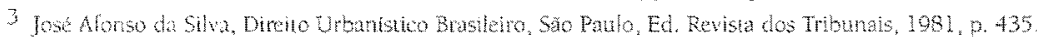


seja ele natural, paisagístico, histórico, artístico etc..."4 . $O$ art. 186, II, por sua vez, ao delinir o conteudo positivo da função social da propriedade rural, inclui, dentre os requisitos para o seu cumprimento, a utilizaçăo adequada dos recursos naturais disponiveis e a preservação do meio ambientes, fazendo deste - não mais uma restrição administrativa heteronônica, externa ao núcleo dominical senão - elemento interno, essencial e definidor do núcleo de poderes do proprietário.

Também em tema de responsabilidade civil, grande é a transformação advinda com a proteçăo ao meio ambiente. $\mathrm{O}$ art. 21, inciso XXII, alínea c, traz previsão expressa de responsabilidade objetiva do causador de danos nucleares, adotando aqui, nitidamente, a teoria do risco. O mesmo preceito, em sua alínea a, estabelece medida preventiva, ao dispor que "toda a atividade nuclear em território nacional somente será admitida para fins pacilicos e mediante aprovação do Congresso Nacional".

De outra parte, o art. $37, \& 6^{\circ}$, estende a responsabilidade objetiva a todos os danos causados pelo agente das pessoas jurídicas de direito público e das pessoas jurídicas de direito privado prestadoras de serviços públicos, o que se aplica, naturalmente, à matéria ambiental, vinculando todos os agentes do Poder Público que causem danos ao meio ambiente.

Aliás, o legislador especial, já anteriormente à Constituiçăo de 1988 , no art. 14, \& $1^{\circ}$, da Lei n. ${ }^{\circ} 6.938 / 81$, que estabelece a Politica Nacional do Meio Ambiente, dispunha:

$" \$ 1{ }^{\circ}$ Sem obstar a aplicação das penalidades previstas neste artigo, é o poluidor obrigado, independentemente da existência de culpa, a indenizar ou reparar os danos causados".

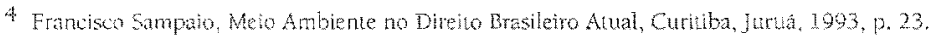

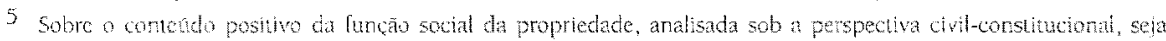

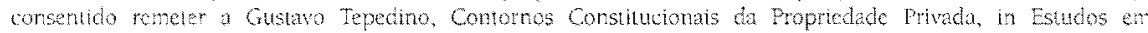

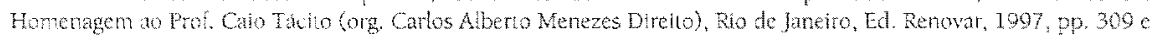
$\operatorname{seg} 5$

6 A muter e trata em profundidnde pror Francisco Sampaio, Responsabilidade Civil e Repanca de Danos ro Meio

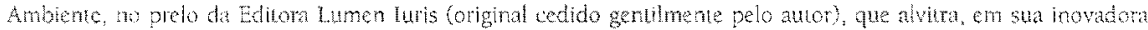

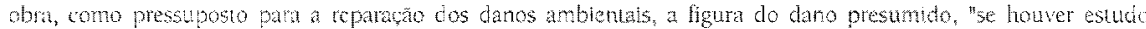

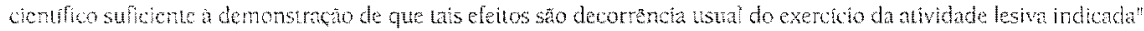


Isto significa que, nas açöes coletivas, quando o objeto se referir a dano ambiental, incide a responsabilidade objetiva, seja o agente pessoa física ou jurídica, de direito público ou privado, bastando ao autor provar o dano, o nexo de causalidade e a atribuição ao réu da atividade danosa.

Corrobora-se aqui, no plano da tutela coletiva, a profunda alteração na dogmática tradicional provocada pelas novas demandas relacionadas ao melo ambiente, que exigiu uma intervenção do constituinte e do legislador especial compativel com as exigências vitais de um meio ambiente equilibrado.

\section{Papel do Ministério Público como agente de efetivação da} tábua axiológica constitucional. A função promocional do Ministério Público

Agente privilegiado de tutela do meio ambiente e dos demais interesses coletivos e o Ministério Público, cuja atividade fiscalizadora, extremamente ampliada, enfrenta ora resistências corporativas, ora objeçōes ideológicas, ora pura e simples incredulidade.

Não é dificil compreender os dois primeiros obstáculos, em um país de problemas múltiplos e complexos como o Brasil. Entretanto, verifica-se que a descrença em relação às novas atribuiçōes decorre da incompreensão, não raro localizada também no seio da própria instituição, acerca do papel do Ministério Público no projeto constitucional.

A rigor, as intermináveis discussões que se têm travado sobre o tema parecem restritas ao exame das atribuiçoes do Ministério Público do ponto de vista estrutural - isto é, o conjunto de poderes postos a disposição do parquet. Não tem sido objeto de suliciente reflexão, no entanto, o perfil da instituiçào em seu aspecto funcional - vale dizer, a função (axiológica) atribuida pela Constituição ao Ministério Público. Sem tal definição, preliminar e impostergável, năo se consegue compreender os instrumentos e o con unto de atividades que the foram cometidos pelos constituintes. 
No liberalismo, como se sabe, o Estado limitava-se a ditar as regras do jogo, emanando leis que, conhecidas previamente por todos, permitiam à livre iniciativa desenvolver-se ilimitadamente. É a sublimação do individuo, suporte ideológico que, com a derrubada da nobreza, destacou a igualdade formal - "todos são iguais perante a lei" - como elemento demarcador do fim dos privilégios feudais e da ingerência do Poder Público em favor de interesses privados. Na conhecida expressão de Stefan Zweig, cuidava-se da "era da segurança", restando ao Estado, verdadeiro veilleur de nuit (Lassalle), o papel de fazer respeitar às leis e coibir os atos ilícitos, sem interferir na atividade e nos objetivos económicos, entregues à inteligência de cada um e aos riscos inerentes aos negócios ${ }^{7}$.

Tal ideologia seria absorvida, na virada do século, pelo Código Civil, não obstante as transformaçōes que, desde a metade do século, alteravam o panorama juridico dos países europeus, indicando uma crescente intervenção do Estado na economia. Movimentos sociais e filosóficos, assim como a evoluçào econômica, serviram para desmistificar a crença igualitária da revolução francesa.

Formou-se, pouco a pouco, uma casta de novos privilegiados, com o sistema de liberdade negocial instaurado, consolidando-se desigualdades näo transponiveis espontaneamente, e que recrudesciam pela garantia (do cumprimento obrigacional inexorável e inelutável) conferida à parte mais forte das relaçóes contratuais, em detrimento dos contratantes em situação de inferioridade. O marxismo concebeu, pela primeira vez, a propriedade năo mais como (expressão e) expansão da inteligência humana, mas, de forma pragmática, como mercadoria, ou elemento mobilizador de riqueza, objeto de troca e de supremacia do capital sobre o trabalho. Para a doutrina marxista, com efeito, o direito de propriedade apresentava-se "como direito sobre o trabalho alheio", assinalando-se a "impossibilidade para o trabalhador de apropriar-se de próprio produto":

\footnotetext{
7 sobre a intuencia desse periodo historico e tos valores do liberalismo nas relacoes contratuais, watalino Inti, Leta

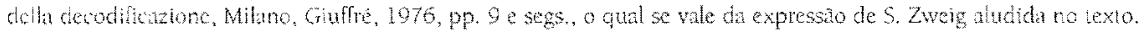

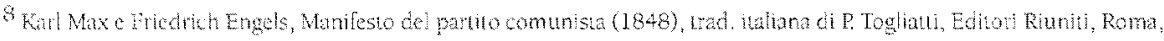
$298,2^{\mathrm{k}} \mathrm{ad}, \mathrm{p} . \mathrm{q}_{\mathrm{w}}$
} 
A Primeira Guerra, na Europa, marcaria, então, definitivamente, a modificação do papel do legislador, antes mero árbitro das relações privadas. O Estado, primeiro de maneira excepcional, e depois sistematicamente, intervém na economia, objetivando impedir a expansăo das desigualdades e atender os interesses básicos da população carente. Os "sem-terra", os "semteto", as legiōes de sub-empregados, os desassistidos dos servicos básicos formam um robusto contigente reivindicante, fomentador de notaveis movimentos sociais, no âmbito dos quais a revolução bolchevique e a experiència constitucional de Weimar servem de pontos de referência.

Países como a França, a Inglaterra e a Itália sofrem radical alteração legislativa, processo identificador do chamado Welfare State, que não mais se limita a mediar as relações privadas e controlar as regras do jogo, passando a intervir, incisivamente, em busca de objetivos fundamentais de justiça social. A meta da justiça retributiva, conquista da revolução francesa, dá lugar à justiça distributiva, com o acentuado intervencionismo estatal e o dirigismo contratual que, no Brasil, é fartamente documentado a partir dos $\operatorname{anos} 30^{3}$.

O estuário desse processo histórico identifica-se, no Brasil, com a Constituição de 1988 que, ao lado do princípio de isonomia formal enunciado no art. $5^{\circ}$ ("Todos săo iguais perante a lei, sem distinção de qualquer natureza"), introduz o principio da igualdade substancial de que trata o art. $3^{\circ}$, III (constitui objetivo da República "erradicar a pobreza e a marginalização e reduzir as desigualdades sociais e regionais"), consagrando, portanto, a justica distributiva (a cada um segundo as suas necessidades).

Tão profunda alteração do papel e dos objetivos do Estado implica a radical transformação das funções do Ministério Público. A preservação da ordem pública, cometida ao parquet, não se identifica mais com a aplicação de sanção pelo descumprimento de leis. E o gendarme notumo, mero observador dos protagonistas sociais em ação, toma-se agente ativo e protagonista central, ele próprio, das transformações impostas à sociedade pelo constituinte.

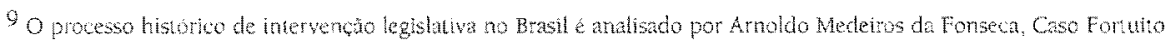

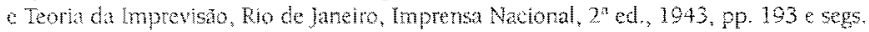


Por outro lado, se a repressão ao ilícito nada mais é que a reprovação de comportamentos considerados extravagantes à ordem pré-estabelecida, a atuaça dos membros do Ministerio Público, no Estado liberal, tinha característica nitidamente conservadora e repressora.

Não por acaso a sociedade atribui ao promotor de justiça do passado o estigma de solene, grave e conservador - e por que não dizer carrancudo, aquele que apenas atua na esfera penal e que, no civel, não se sabe bem a que veio. Afinal, na ideologia do liberalismo o próprio direito era concebido como instrumento de manutenção de uma ordem pública em que o Estado deveria estar distante da atividade economica. O direito atuava, portanto, somente de maneira a reprimir ilícitos - tudo que năo é proibido é permitido - e o Ministério Público haveria de cumprir o papel de zelar por aquela ordem pública, historicamente determinada. Não há qualquer demérito em relação a esse tipo de atuaçảo. O que importa assinalar, no entanto, é que tal função responde a uma lógica e a uma ideologia condizentes com o sistema positivo do passado, inteiramente diversas das que hoje presidem o ordenamento juridico.

A passagem para o Estado Social, portanto, coincide com a alteraçăo do papel do direito, que adquire, conforme entreviu Norberto Bobbio, verdadeira funçăo promocional ${ }^{10}$, identificava na intervenção normativa destinada a promover os valores definidos pelo Estado. Alteram-se radicalmente os parâmetros da ordem pública e os meios de tutelá-la.

A garantia de preservação desta nova ordem pública foi atribuída pelo constituinte de 1988 ao Ministério Público, alçado assim pela Constituição Federal a principal agente de promoção dos valores e direitos indisponiveis, situados no véntice do ordenamento. Trata-se de atribuição distinta da que, no sistema pré-vigente, fora cometida aos membros do parquet. O Ministério Público adquire assim uma função promocional, coerente com o papel definido para o Estado nos princípios gerais da Constituição e especificado pelo ari 129 do Texto Maior.

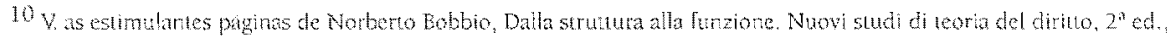
Miano, Edzoni di Comunia, 1984, $\left(1^{7} \mathrm{~cd} .1977\right)$.
} 
Do Ministério Público não se exige apenas coibir ilícitos, as lesões perpetradas contra bens de interesse público, situando-se, ao revés, entre as suas funções institucionais, a promoção de medidas necessárias à garantia dos serviços de relevância pública e dos direitos assegurados na Constituição (art. 129, I), a promoção do inquérito civil e da ação civil pública para a proteção de qualquer interesse difuso ou coletivo (art. 129, III).

Em outras palavras, o Ministério Público deixa de atuar simplesmente nos momentos patológicos, em que ocorre lesão a interesse público, sendo convocado a intervir de modo permanente, promovendo o projeto constitucional e a efetividade dos valores consagrados pelo ordenamento.

O promotor de justiça, antes identificado quase que exclusivamente com a promoção da ação penal, transforma-se no promotor de valores, para cuja tutela a ação judicial não é mais do que um de seus instrumentos. Não mais aguarda o inquérito ou o processo para, só então, pronunciar-se, devendo, ao contrário, buscar os meios de tutela mais adequados e avocar a si a iniciativa da clefesa da sociedade.

Essa intervenção ativa e direta, por sua vez, através de atuação judicial ou extrajudicial, não há de ser aleatória, tendo conteúdo claramente estabelecido pela Constituição em seus princípios gerais, que delinem os objetivos e os fundamentos da República, suscitando a reavaliaçăo, em sede interpretativa, de postulados que, por muito tempo, passaram clespercebidos pelos juristas.

Não se poderiam aqui percorrer as inúmeras hipóteses de atuação do Ministério Público, o qual, na defesa da sociedade, promoverá a tutela dos valores eleitos como prioritários pelo ordenamento constitucional. A título exemplificativo, no entanto, poder-se-ia afirmar que, nas relações de trabalho, a saúde e a dignidade do trabalhador devem servir de parâmetro para o controle da atividade econômica, ainda quando não ocorra o acidente de trabalho propriamente dito. Nem se poderá admitir a troca da integridade psicofísica do empregado por um adicional de insalubridade abstratamente considerado, quando o respeito formal ao acréscimo da remuneração implique o sacrifício da saúde, da dignidade ou da expectativa de vida. Também as relaçōes de consumo, a atuação empresarial e sua interação com 
o meio ambiente, a utilização do patrimônio público, todas essas atividades terão tutela juridica condicionada ao respeito dos valores constitucionais, cuja promoçăo permanente e incessante é cometida ao Ministério Público.

A consecução de tais objetivos, entretanto, está a exigir uma mudança de mentalidade bastante profunda que deverá iniciar pelo convencimento de que a Constituição da República não é uma Carta Política a enunciar principios destinados exclusivamente ao legislador, desprovida de forca nomativa e de efetividade imediata.

Procura-se daqui e dali construir uma espécie de efecividade seletiva das normas constitucionais. Năo parece demasiado afirmar que a cultura juridica dominante criou duas Constituicões. Há uma Constituição que vem sendo zelosamente aplicada, tomada em retalhos, disciplinadora de certos princípios da ordem e da manutencão do domínio econômico, da estruturação do Estado e dos Poderes e da República. É, de fato, o Texto Maior. E hả outra Constituição, transformada numa espécie de carta de intençōes, que assegura os direitos indispensáveis à cidadania e à dignidade do homem, tendo como princípio fundamental a erradicaça da pobreza e a diminuiça das desigualdades sociais. Esta loi reduzida, de fato, ao Texto Menor.

A reforma agrária, a previdência social, a saúde pública, a educação básica, prioridades constitucionais, integram a Carta Menor. Tais metas, cruciais para o exercício da cidadania, são destinadas ao esquecimento ou à malversação, ao mesmo tempo em que os revezes impostos à sobrevivência retiram o lólego reivindicacionista dos grupos organizados, relegados as lutas corporativas, contingenciais e localizadas.

Ao Ministério Público cabe a tarefa - nada simples - de unificar o sistema constitucional assim fragmentado, pugnando pela efetividade dos interesses sociais indisponiveis, os quais devem servir, a um só tempo de leitmotiv e de limite, escapando de suas atribuiçoes institucionais a tutela de interesses que, embora coletivos, e atinentes a matérias que lhe seriam próprias, não apresentam a relevância social e a indisponibilidade que caracterizam a ordem pública no sistema constitucional vigente. 
Renunciar à concepção segundo a qual o texto constitucional é uma carta meramente politica, significa sublinhar os principios fundamentais do ordenamento. $O$ art. $1^{\circ}$, III, elege como fundamento da Repúbica a dignidade da pessoa humana. $\mathrm{O}$ art. $3^{\circ}$, III, afirma constituir objetivo fundamental da República a erradicação da pobreza e da marginalização, bem como a reduçăo das desigualdades sociais e regionais. Há que se perquirit o significado nomativo de tais enunciados. Cuida-se em realidade de opção prioritária do constituinte, traduzida em norma jurídica situada no vértice do ordenamento e que, por isso mesmo, deve permear todo o tecido legislativo infraconstitucional, bem como a atividade do poder Executivo e as relaçóes de direito privado. Não se justilicariam tais dispositivos gerais, topograficamente precedentes aos títulos especficos, näo fossem para eleger a pessoa humana como valor prioritário e a justiça distributiva como caracteristica do Estado.

A partir de tais postulados, toda a atividade estatal e a iniciativa econômica privada tornam-se vinculadas ao atendimento dos valores constitucionais indicados. Isto é, a atividade estatal e empresarial merecerá tutela juridica se - e somente se - preservar e promover os princípios e objetivos de República enunciados como norma juridica de vigência e eficácia plena, situados que estão no topo do ordenamento.

3. A acão civil pública como instrumento privilegiado de exercício coletivo da cidadania aspectos controvertidos: a) o objeto da ação civil publica; b) a defesa dos interesses individuais homogêneos pelo Ministério Público; c) olitisconsórcio do Ministério Público Federal com o Ministério Público dos Estados; d) O local do dano e a competiencia funcional-territorial para a propositura da ação. A Súmula N. 183 do STJ

Muitas loram as controvérsias que floresceram com o surgimento, no cenário juridico brasileiro, da ação civil püblica, que se constitui talvez no principal instrumento posto à disposição do novo Ministério Púbico. A 
natural dificuldade dos operadores diante de um instituto completamente novo, soma-se a argúcia das teses de defesa, que procuraram restringir a amplitude da ação civil pública, quer quanto ao seu objeto, quer quanto a aspectos subjetivos, valendo enfrentar alguma das polêmicas que ainda agitam os tribunais, dentre as quais, se destaca, certamente, a determinação de seu objeto.

\section{a) O objeto da aça civil püblica}

0 art. $1^{\circ}$ da Lei n. ${ }^{\circ} 7.347$, de 24.7 .85 , que regula a ação civil pública, tem dicção deliberadamente ampla, sendo assim vazado:

"Art. 10. Regem-se pelas disposiçōes desta lei, sem prejuizo da ação popular, as açóes de responsabilidade por danos morais e patrimoniais causados:

I - ao meio ambiente;

II - ao consumidor;

III - a bens e direitos de valor artístico, estético, histónico e paisagístico; V - a qualquer outro interesse difuso e coletivo;

$\checkmark$ - por infração da ordem econômica."

Ao dispositivo, que teve o inciso $\mathrm{V}$ introduzido pelo art. 88 da Lei n. ${ }^{\circ}$ 8.884, de 11.6.94, e o inciso IV acrescentado pelo art. 110 do Código de Defesa do Consumidor, hâ de ser acostadas a Lei n. $7.853 / 89$ (tutela dos portadores de deficiencia), a Lei n. $7.913 / 89$ (mercado de valores mobiliánios) e a Lei n. $8.069 / 90$ (Estatuto da Criança e do Adolescente), para que se tenha delineado o amplo panorama em que se insere a aça civil publica.

O fato é que o legislador especial, como se vê, ao lado da previsão especifica de interesses a serem resguardados com a ação civil pública, utiliza-se da cláusula geral do inciso IV acima transcrito, de modo a que qualquer interesse de dimensão coletiva, nos termos especificados pelo 
Código de Defesa do Consumidor, possa ser tutelado nos termos da Lei n. ${ }^{\circ}$ $7.347 / 85$.

Rompe-se, desse modo, a técnica do numerus clausus adotada anteriormente pela Lei ${ }^{\circ}{ }^{\circ} 7.347 / 85$, na mesma esteira do constituinte que, ao definir as funções institucionais do Ministério Público, no art. 129, III, vale-se da referência genérica a outros interesses difusos e coletivos. Em outras palavras, a Lei n. ${ }^{\circ} .347 / 85$, recepcionada pelo sistema constitucional, adquiriu, paulatinamente, novos contornos, espraiando sua disciplina processual para as hipóteses de violação de interesses difusos e coletivos de qualquer natureza".

Por outro lado, a dicção do art. $3^{\circ}$, segundo o qual "a ação civil poderá ter por objeto a condenação em dinheiro ou o cumprimento de obrigação de fazer ou não fazer", associada à previsão do fundo de defesa dos interesses difusos (regulado pela Lei n. ${ }^{\circ} 9.008$, de 21.3.95), destinado à recuperação dos bens atingidos, faz com que se possa cogitar de formulação de pedido vário, desde que compativel e necessário à obtenção da tutela pretendida.

Discute-se se o teor do art. $3^{\circ}$ acima mencionado reduziria o conteúdo do pedido na ação civil pública à natureza condenatória, excluindo-se as hipóteses de objeto de conteúdo constitutivo, o que diz respeito diretamente às açoes em que se visa à anulação de atos lesivos a bem juridico coletivamente tutelável.

A matéria tem suscitado aceso debate em torno da tutela do patrimônio público e social, nas ações civis públicas propostas pelo Ministério Público em sua defesa, quando argumentou-se que somente a ação popular poderia ser destinada à anulaçăo dos atos impugnados. De fato, o art. $1^{\circ}$ da Lei n. $.^{\circ} 4.717 / 65$, ao contrário da Lei n. ${ }^{\circ} 7.347 / 85$, refere-se

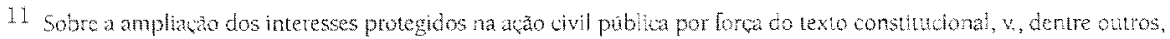

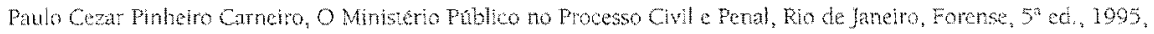

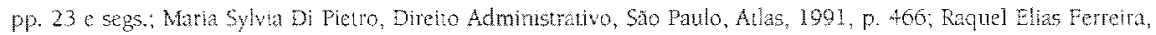

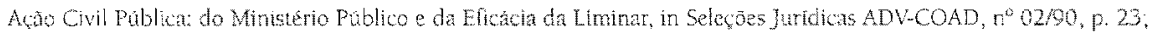

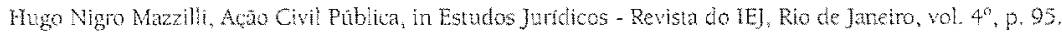


expressamente à legitimidade de qualquer cidadão para pleitear a anulaçāo ou a declaração de nulidade de atos lesivos ao patrimônio público.

A restriçăo, contudo, não merece acolhida, à luz de uma interpretação teleológica da Lei n. 7.347/85, que pretende oferecer tutela ampla aos interesses coletivos, parecendo mesmo que, neste diapasão, o legislador especial admite, como implícito ao pedido condenatório alvitrado pelo art. $3^{\circ}$, as providências de caráter declaratónio e constitutivo que a condenaça pressupõe - ou que são dela pressuposto.

No caso do Ministério Público, o argumento encontra-se reforçado pela amplitude da garantia constitucional insculpida no art. 129, II, segundo o qual, como já antes analisado, é função institucional do parquet "promover o inquérito civil e a ação civil pública, para a proteça do patrimônio público e social, do meio ambiente e de outros interesses difusos e coletivos". Ora, onde o constituinte nâo restringiu não caberia ao intérprete fazê-lo, máxime quando a legislação especial, disposta através da técnica das cláusulas gerais e exemplificativas, denota vocação expansionista.

Como se não bastassem, a Lei Orgânica Nacional do Ministério Público, Lei n. $8.625 / 93$, no art. 25, IV, b, comete expressamente ao Ministerio Público o ajuizamento de ação civil pública "para a anulação ou declaração de nulidade de atos lesivos ao parrimônio público ou à moralidade administrativa do Estado ou de Município, de suas administraçoes indiretas ou fundacionais ou de entidades privadas de que participem", dissipando, assim, qualquer dúvida quanto à ampliação do objeto da açăo civil pública, ao menos no que tange à legitimidade do Ministério Público na defesa do patrimônio público e da moralidade administrativa' ${ }^{2}$.

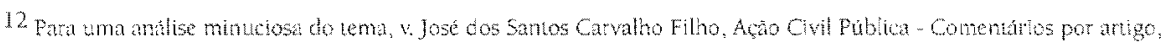
Rio de Janeiro, freitas Rastos, 1995, pp. 54 e segs., o qual traz à olaça dois interessantes casos judiciais. No primeiro deles, objeto da Apelayan Cvel $n^{2} 29.976-8$, prolatado pela $2^{2}$ Camara Civel do Tribunal de Justica de Minas Gerais (D) de 14.895, in ADCOAS, $\mathrm{n}^{\circ}$ 1.001.179), sendo relator o Des. Rubens Xavier Ferreira, em que se acmie a lcgitmidade do Ministerio Público para tntentar aço civil publica qisando à anulaçăo de atos lesivos ao crario,

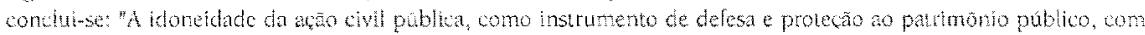
manejo asscguralo pelo ant. 129. UI, da CF, adquiriu amplitude maior do que aquela previsa na Le n" 7.347/85, molivo por que sust propositura e a legituidade do seu patrocinador so devem encontrat obstatulo nos casos de 
Restaria dúvida, no entanto acerca da possibilidade de formulação de pedidos de natureza constitutiva quando a parte autora näo for o Ministério Público ou quando o pedido visar à tutela de bens diversos dos atinentes ao patrimônio público e à moralidade administrativa. A matéria, vê-se de logo, é controvertida, inexistindo previsão autorizadora expressa. Todavia, coerentemente com a posição acima enunciada, em homenagem seja à ratio da Lei n. ${ }^{\circ} 7.347 / 85$, destinada à proteção coletiva e ampla de bens jurídicos indisponiveis, seja à técnica adotada pelo legislador, que não pretendeu ser taxativo ou regulamentar, preferindo sempre as claúsulas gerais, seja, enfim, ao principio da igualdade das partes projetado no campo processual, näo é de se admitir restriçōes ao objeto da ação civil pública, sendo esta capaz de comportar a tutela declaratória, constitutiva e condenatória.

Não se justificam, portanto, nos termos da Constituição e da lei especial, as restriçoes ao pedido a ser formulado na ação civil pública, que a colocassem, neste aspecto objetivo, em posição de inferioridade em relaçăo à ação popular regida pela Lei n. ${ }^{0} 4.717$, de 29.6.65. De modo que, a despeito das numerosas e respeitadas vozes em contrário ${ }^{13}$, parece que a distinção entre os dois tipos de ação se encontra no plano subjetivo, distinguindo-se ambas pela legitimidade processual, sendo a ação popular o instrumento privilegiado para o exercício jurisdicional da cidadania, e a ação civil pública a expressão maior da tutela da sociedade organizada, ora no âmbito associativo, ora através do Ministério Público, como tradução de sua antes enunciada funçāo promocional.

evidente contratiedide ao ordenamento". O segundo, relatado pelo mesmo autor ( $p .56)$, fo amplamente veiculado pela imprensa no ano de 1994, quando o Ministério Publico do Estado do Rio de Janeiro impugnou a nomeacâo pelo Governador do Estade de ceno Deputado para o cargo de Conselheiro do Tribunal de Contas Estadual, ao argumento de que o nomeado no preenchia o requisio da moratidade administrativa necessario para ocupa-lo "o Procurado: Geral de Justica ajuizou acáo civil pública visando a impedir a posse do nomeado (pedido de conteúdo condenalerio), como tambem para anular o ato de nomeaço por vicio em seu molvo (pedico de coneudo constublvo), o pedido só foi jur idicamente possivel pelo fato de ser a motalidade administrativa o interesse difuso a ser protegido".

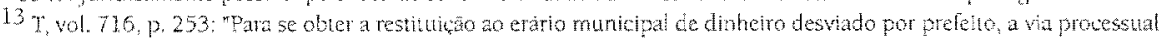

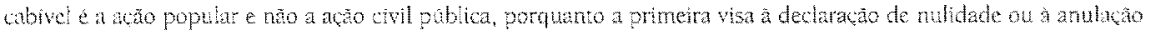
dos atos lesivos ao patrimöno publico e a moralitade acministrativa e a segunda destina-se a protetäo de deleminados diretos e interesses difusos ou coletivos previstos en lei espechica". Mas, a rigor, poder-se-ia indagyr: como poteger lais diretos sem que se pudesse fommiar o pedito de reomposica do erario publico, quando for o ctso? 


\section{b) A defesa dos interesses individuais homogêneos pelo}

\section{Ministério Público}

Outra questão extremamente polêmica e ainda não pacificada referese à possibilidade de propositura de ação civil pública pelo Ministério Público para a defesa de interesses individuais homogêneos. A discussão normalmente vem à tona em hipóteses concernentes às relações de consumo, embora se enquadre, perfeitamente, nos casos de lesão ao meio ambiente, subsumindo-se na definição estampada no art. 81, III, do Código do Consumidor.

A rigor, não seria exagero afirmar que, em termos práticos, as lesões a interesses coletivos ou difusos normalmente implicam a configuração de interesses individuais homogêneos, sendo muito difícil isolar cada uma dessas espécies de interesses, de modo a que se pudesse identificar, diante de uma hipótese concreta, a presença do interesse estritamente coletivo ou exclusivamente individual homogêneo. Daqui a conclusão inelutável de que, nas relações de consumo, a restrição ao Ministério Público de atuação na defesa dos interesses individuais homogêneos significa, praticamente, a obstrução de suas funções institucionais.

A Constituição Federal, como antes demarcado, atribui ao Ministério Público a função de promover a ação civil pública para a defesa do patrimônio público e social, além de outros interesses difusos e coletivos (art. 129, III). O Texto Maior trata, assim, dos interesses coletivos de maneira genérica (sentido lato), deixando ao legislador especial a tarefa de especificar as diversas categorias ou espécies de interesses e ações coletivas ${ }^{14}$.

\footnotetext{
14 V., sobre o tema, Kazuo Watanabe, Comentários ao art. 81 da Lei $n^{\circ} 8.078 / 90$, in Código Brasileiro de Delesa do Consumidor, Rio de Janeiro, Forense Universitária, 1991, p. 511 , para quem a aço para a delesa dos interesses individuais homogêneos é uma "modalidade de ação coletiva". O mesmo autor observa (in Demandas Coletivas e Problenas Emergentes da Praxis Forense, in As Garantias do Cidadāo na Justiça (coord. Sálvio de Figueiredo, Saraiva, 1993, pp. 118 e segs.) que "a tutela coletiva abrange não somente os interesses e dircitos essencialmente coletivos, que são os difusos e coletivos propriamente ditos, como também os de nalureza coletiva apenas na forma en que sāo utelados, que sio os "individuais homogéneos", definidos no art. 81 ...".
} 
Na esteira de tal regulamentaçăo, a Lei n. ${ }^{\circ} 8.078 / 90$, o Código de Defesa do Consumidor, em seus arts. 81 e seguintes, prevê três espécies de interesses coletivos, a suscitarem a chamada defesa coletiva, aí incluindo-se os interesses individuais homogeneos. Por outro lado, o art. 117 da Lei n. ${ }^{\circ}$ $8.078 / 90$ introduziu o art. 21 na Lei n. $7.347 / 85$, determinando a aplicação dos dispositivos constantes no Título III do Código de Defesa do Consumidor às açōes civis públicas. Daí, portanto, a indiscutivel legitimidade do Ministério Público para atuar na proteção dos direitos individuais homogêneos.

Todo esse gênero de interesses comporta a tutela processual coletiva através da ação civil pública, por força do aludido art. 1.17 do mesmo diploma, sendo o Ministério Público legitimado para a sua defesa. Não Cossem os preceitos antes mencionados, poder-se-ia invocar, ainda, a Lei Complementar n. 75/93, cujo art. $6^{\circ}$, XII, estabelece:

"Art. $6^{\circ}$ Compete ao Ministério Público da União:

XII - promover ação civil pública para defesa de interesses individuais homogêneos."

A jurisprudència dos Tribunais Estaduais e Regionais, a seu turno, vem consagrando, paulatina e decididamente, a legitimidade do Ministério Público para a defesa de direitos individuais homogêneos atinentes às relacoes de consumo ${ }^{15}$. Na mesma direçao posiciona-se o eg. Superior Tribunal de Justiç, valendo transcrever acórdão proferido à unanimidade de votos pela $1^{\text {a }}$ Turma, sendo relator o Ministro Demócrito Reinaldo, no R. esp. n. ${ }^{\circ} 49.272-6-\mathrm{RS}^{16}$.

"Açăo civil pública para defesa de interesses e direitos individuais homogêneos. Taxa de iluminação pública. Possibilidade.

A Lei n. ${ }^{\circ} 7.345$, de 1985 , é de natureza essencialmente processual, limitando-se a disciplinar o procedimento da ação coletiva, e não se

15 C. RT 689134; 601/170; RTRF - 4" Reg. 15/359; 14/309; RJTJ-SP 116/33; 137/312; 149/34; ADVCOAD n" 6678894.

16 D. 17.1094. Sexto $1,27.968$ : 
entremostra incompativel com qualquer norma inserida no Título III do Código de Defesa do Consumidor (Lei n ${ }^{\circ}$ 8.078/90).

É principio de hermenêutica que, quando uma lei faz remissäo a dispositivos de outra lei de mesma hierarquia, estes se incluem na compreensão daquela, passando a constituir parte integrante de seu contexto.

$\mathrm{O}$ art. 21 da Lei n. ${ }^{0} 7.347$, de 1985 (inserido pelo art. 117 da Lei n. ${ }^{\circ}$ $8.078 / 90$ ), estendeu, de forma expressa, o alcance da ação civil pública à defesa dos interesses e "direitos individuais homogêneos", legitimando o Ministério Público, extraordinariamente e como substituto processual, para exercitá-lo (art. 81, parágrafo único, III, da Lei n. ${ }^{\circ} 8.078 / 90$ ).

Os interesses individuais, in casu (suspensão do indevido pagamento de taxa de iluminação pública), embora pertinentes a pessoas naturais, se visualizados em seu conjunto, em forma coletiva e impessoal, transcendem a esfera de interesses puramente individuais e passam a constituir interesses da coletividade como um todo, impondo-se a proteçăo por via de um instrumento processual único e de eficácia imediata - "a aça coletiva".

O incabimento de ação direta de inconstitucionalidade, eis que, as leis municipais n. ${ }^{\circ} \mathrm{S} 25 / 77$ e 272/85 são anteriores à Constituição do Estado, justifica, também, o uso da ação civil pública, para evitar as inumeráveis demandas judiciais (economia processual) e evitar decisões incongruentes sobre idènticas questões juridicas.

Recurso conhecido e provido para afastar a inadequação, no caso, da ação civil pública e determinar a baixa dos autos ao Tribunal de origem para o julgamento do mérito da causa. Decisão unânimell.

De recente, inclusive, o col. Supremo Tribunal Federal proferiu decisão no mesmíssimo sentido, em acordão unànime da lavra do eminente Ministro Maurício Correia, versando sobre aumento de mensalidade escolar e assim ementado:

"Não está, como visto, o Ministério Público defendendo subjetivamente o individuo como tal, mas sim a pessoa enquanto integrante 
deste grupo. Vejo, desta forma, que me permita o acórdão impugnado, gritante equivoco ao recusar a legitimidade do postulante, porque estaria a delender interesses fora da ação definidora de sua competência (...)

Ademais, estava o parquet mais do que impelido a promover a açăo, pelo dever de oficio, quanto mais quando se trata de interesses que se elevam à categoria de bens ligados à educação, amparados, como se sabe, constitucionalmente, como dever do Estado e obrigação de todos (CF, art. 205)".

Nem se objete que tal entendimento levaria a uma legitimaçäo desmesurada do Ministério Público para a defesa de interesses individuais. Em realidade, há dois outros característicos que evitam tal anomalia, determinando perfeitamente a atribuição constitucional do Ministério Público: a indisponibilidade e a alcance social dos direitos tutelados. Dá o equivoco em que incorreu certa decisão judicial que, ao negar a legitimidade do Ministério Público, referiu-se a uma suposta restrição do Superior Tribunal de Justiça à "pertinência subjetiva do parquet quanto à tutela de direito individual homogêneo, na medida em que o mesmo é disponivel e destacável, fugindo a ratio da atuação ministerial" ${ }^{n}$.

A afirmação não resiste à colação da jurisprudência daquela Corte ${ }^{1 s}$. Nem serve de paradigma o Recurso Especial n. 35.644-MG, invocado pela mesma sentença, já que inteiramente inadequado à espécie, por cuidar de interesses que a Corte entendeu, ai sim, particulares, de "um grupo de alunos de um determinado colégio", como consta na ementa do julgado. Não pretendeu o Superior Tribunal de Justiça, comoé de palmar evidència, negar ao Ministério Público legitimidade para a defesa de interesses individuais

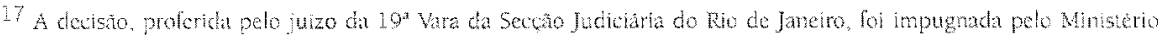

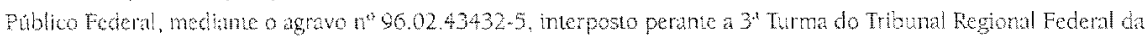

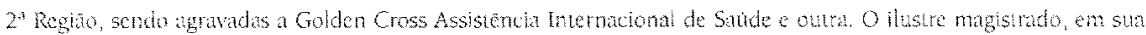

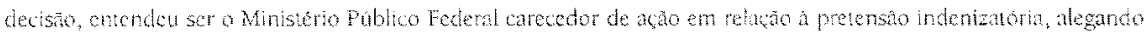

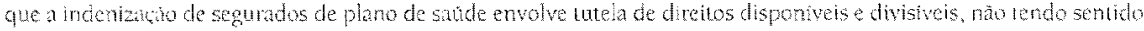

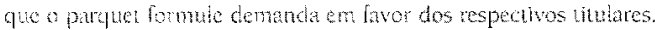

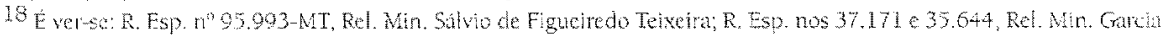

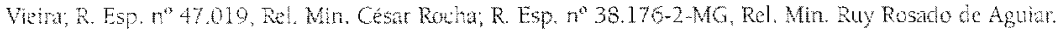


homogêneos: apenas considerou (e o fez sem unanimidade, por maioria de votos) que, na hipótese concreta, aqueles interesses não tinham o alcance social que justificasse a sua defesa pelo parquet ${ }^{19}$.

o mesmo ocorreria, a título de exemplo, se um grupo de latifundiários, unidos por interesse comum, ou um grupo de condominos de um refinado prédio de apartamentos, pretendesse bater às portas do Judiciário, pelas mãos do Ministério Público, para a tutela de seus direitos. A indisponibilidade e o alcance social, portanto, servem de criterios seguros para, no âmbito da tutela coletiva, determinar a legitimidade do Ministério Público para a defesa de interesses difusos, interesses coletivos stricto sensu e interesses individuais homogèneos, todas espécies de açoes coletivas (lato sensu).

acórda antes mencionado, contudo, tem servido de paradigma para hipoteses que the são completamente estranhas, como a sentença acima referida, prolatada em ação civil destinada a tutelar interesses (não de um grupo estreito mas) de milhões de consumidores do serviço de seguro-saúde em todo o país, atingidos pelas cláusulas contratuais abusivas praticadas sem qualquer cerimônia nos contratos de adesão. Diga-se, entre parêntesis, que o sistema privado de saúde brasileiro conta com cerca de 32 milhóes de consumidores, dos quais aproximadamente 16 milhöes vinculam-se aos serviços de seguro-saúde. Ora, afirmar que a pretensão indenizatória torna disponivel e divisivel o direito do segurado significa desvirilizar por completo a atuação ministerial, substraindo-lhe a defesa de qualquer interesse coletivo com repercussăo patrimonial na esfera individual (ou seja: todo e qualquer interesse individual homogêneo, cuja tutela é ao parquet atribuida pelo sistema constitucional e legal, como acima examinado).

A propósito, vale invocar, em apoio à tese aqui desenvolvida, o pensamento da doutrina especializada. Ada Pellegrini Grinover, Professora

\footnotetext{
19 RSTJ, vol. 54, p. 320. Tal conclusiko se depreende, ahas, da propria declaraca de voto vencedor do Mnistro Gomes st Barns: "No chtanto, neste caso, năo se trata examente de tireito coletivo definido pelo an. 81 . O que hat ma

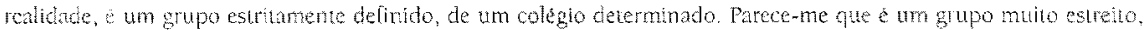
pan comesponder ao esprito to ant. $61^{\text {"n. }}$
} 
Titular da Faculdade de Direito da Universidade de São Paulo, em contribuição especifica sobre o tema, reafirma exaustivamente a "possibilidade jurídica de se buscar, pela via da ação civil púbíica, a reparação dos danos sofridos por particulares, muito embora não se trate de interesses coletivos (indivisiveis): trata-se de interesses (ou direitos) indivicluais homogêneos, tratados coletivamente, igualmente protegidos pela LACP"20. Observa, ainda, a mesma autora que "a relevância social da tutela coletiva dos interesses ou direitos individuais homogeneos levou o legislador ordinário a conferir ao Ministério Público a legitimação para agir nessa modalidade de demanda, mesmo em se tratando de interesses ou direitos disponiveis. Em conformichade, aliás, com a própria Constituiçăo, que permite a atribuição de outras funções ao MP, desde que compativeis com sua finalidade (art. 129, IX). A dimensāo comunitária das demandas coletivas, qualquer que seja seu objeto, insere-as sem dúvida na tutela dos interesses sociais referidos no art. 127 , da CF". E remata, invocando o magistério de Kazuo Watanabe: "Em linha de princípio, somente os interesses individuais indisponiveis estäo sob a proteção do Parquet. Foi a relevância social da tutela a título coletivo dos interesses ou direitos individuais homogeneos que levou o legislador a atribuir ao Ministério Público e a outros entes públicos a legitimaçăo para agir nessa modalidade de demanda molecular, mesmo em se tratando de interesses e direitos disponiveis ${ }^{12 !}$.

Diante de uma questão concreta, deve portanto o magistrado, antes de mais nada, conferir a indisponibilidade e o alcance social do objeto da demanda - na hipótese antes aludida, o direito constitucional à saúde. De qualquer sorte, como releva a melhor doutrina, o caráter coletivo da demanda, em regra, e suficiente para dar aos interesses individuais, posto divisiveis, a dimensão coletiva que caracteriza a atribução do Ministério Público.

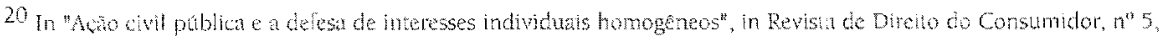
pp. 206 segs c, especiamente, p. 212.

21 Ada Pellegrini Grithoret, ob. cit, p. 213.
} 
A indisponibilidade dos direitos individuais homogêneos, por outro lado, näo é obscurecida pela patrimonialidade das pretensões individuais. O que releva é a indisponibilidade do interesse atingido pela relação jurídica original, que serve de base para a demanda comum. Uma vez atingidos direitos fundamentais do homem, como a saúde, a educação, o meio ambiente, tem-se por violados interesses indisponiveis, ainda que desses mesmos interesses deconam danos conversiveis em parcela patrimonial indivichalizada em relação a cada um dos titulares da açăo.

Se assim não fosse, far-se-ia tábula rasa das demandas coletivas já que, em regra, as pretensóes ressarcitórias resultam na expressão patrimonial das violaçós dos interesses extrapatrimoniais e indisponiveis atingidos. A dimensão coletiva da demanda, com efeito, posta a lume no excerto da Professora Ada Grinover, desde que socialmente relevantes os interesses em jogo, parece cada vez mais capaz de tomar indisponíveis os pleitos individuais.

Nesta direçäo, entendeu-se que "quando tais interesses individuais homogêneos, mais que a soma de situações particulares, possam ser qualificados como de interesse comunitário, nos termos acima enunciados, não há dúvida de que o Ministério Público estará legitimado a atuar ${ }^{1122}$. Em posiço ainda mais avançada, afimou-se, em recentíssima contribuiçâo sobre o tema, que "os interesses, quando tratados coletivamente, sejam quais forem, perdem o caráter de disponibilidade, traço que somente os identificará em sua dimensāo individual". Mais anda: "os interesses individuais - deduzidos de forma coletiva tornam-se indisponiveis, tanto para o adequado portador que se apresenta a juízo, como pelo grupo de vítimas, seus titulares. Da mesma forma preleciona Antonio Gidi, adjetivando como 'lalacioso'o argumento que rejeita o caráter social da proteçăo ao direito patrimonial individual disponivel ${ }^{123}$.

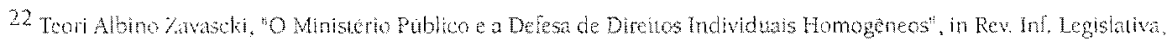

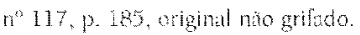

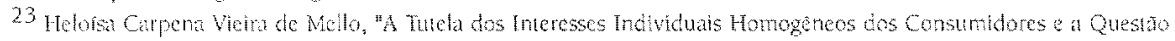

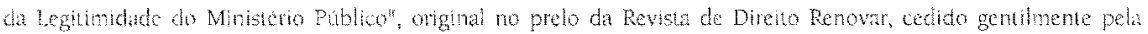
atilonia.
} 
Resulta dai, como evidente a mais não poder, a legitimidade do Ministério Público para atuar na defesa dos interesses individuais homogéneos, notadamente quando versar a controvérsia sobre interesses dervados de direitos indisponiveis e socialmente relevantes (como é o caso do meio ambiente ou da saúde dos consumidores).

\section{c) Litisconsórcio entre os Ministérios Püblicos da União, do Distrito Federal e dos Estados}

Outra tormentosa discussäo, ainda hoje acesa, refere-se à previsăo, insculpida pelo legislador especial, de litisconsórcio entre os diversos ramos do Ministério Público da União, do Distrito Federal e dos Estados, bem como a possibilidade destes últimos, em consequência da atuação conjunta, postularem na Justiça Federal.

Sustentam ilustres doutores, incluindo ai eminentes membros do Ministério Público Federal, que o litisconsórcio assim formado violaria o principio federativo, com a contrariedade dos arts. $1^{\circ}, 25$, e $\$ 1^{\circ}$ e $128 \mathrm{da}$ Constituição Federal. Alima-se que o princípio federativo "pressupóe distribuição de competências e atribuições" e que "a Federaçõo implica que os órgàos de cada entidade federativa cuidem dos assuntos relacionados à sua área de atuação". Em remate, lança-se a interrogação: "Se não fosse assim, para que se criarem órgãos distintos e, em consequência, se distribuirem atribuiçôes?"24 .

A argumentação, entretanto, em que pese a cultura juridica de seus fautores, parte de falsa premissa interpretativa, segundo a qual, no ordenamento constitucional vigente, a atribuição do Ministério Público coincide perfeitamente com a distribuição de competencia jurisdicional. Com efeito, o que poderia ser verdade sob a égide do regime constitucional

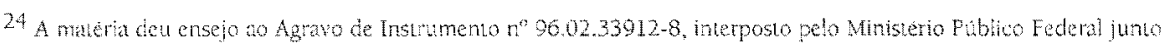
no Trbunat Regional Foderal da $2^{2}$ Regin̆o, no ambito do qual manifestei-me atraves de parecer on sintetizado.
} 
anterior, invocado e reavivado por renitente misoneismo, não há de se repetir sob o texto de 5 de outubro de 1988 . E é bem fácil entender o porquè.

A Constituição Federal de 1988, ao conceber o Ministério Público com autonomia funcional e administrativa (art. 127, CF), desvincula suas atividades institucionais da órbita do Poder Executivo ou do Judiciário, ao mesmo tempo em que, deliberadamente, prevê funçoes ministeriais extrajudiciais, vinculando sua atuação não a órgãos ou Poderes mas a interesses, constitucionalmente tutelados. Assim é que, embora essencial à funçào jurisdicional do Estado, a teor do art. 127 da Constituição, a atuação do Ministério Público năo guarda qualquer paralelo com a do Poder Judiciário, incumbindo àquele a defesa da ordem juridica, do regime democrático e dos interesses sociais e individuais indisponiveis, missão para a qual poderá, se necessário, recorrer à Justiça.

É precisamente por este motivo que, não obstante persista aqui e ali o entendimento comprometido com o regime pré-constitucional do sistema das competências, a maior parte das atividades do parquet, nos dias de hoje, é extrajudicial, particularmente no que tange à defesa dos interesses difusos e coletivos. O Ministério Público deixa de ser configurado como instituição reativa para assumir função institucional ativa, exercendo a fiscalização por meio de inquérito civil público, recomendações, inspeçoes, termos de ajustamento de condutas etc. Da mesma forma, não há qualquer vedação constitucional ou legal a que o Ministério Público Estadual possa atuar na Justiça Federal, desde que comprove a legitimidade processual, vale dizer, a pertinência do pedido com o seu âmbito de atuação institucional.

De outra parte, quis o constituinte, no $\$ 5^{\circ}$ do art. 128 , atribuir às leis complementares a tarefa de estabelecer a organização, as atribuiçócs e o estatuto de cada ramo do Ministério Público, o que, só por si, serve a afastar qualquer pecha de inconstitucionalidade que pudesse ser lançada contra as leis complementares e ordinárias que regulam a atuação ministerial.

E de fato, segundo as leis complementares em vigor, que cuidam do Ministério Público, a tutela dos interesses constitucionalmente protegidos 
deve ser perseguida a todo custo, determinando a Lei Complementar $n .{ }^{\circ}$ $75 / 93$ que "somente a lei poderá especificar as funçóes atribuidas pela Constituiçăo Federal e por esta Lei Complementar ao Ministério Público da União" (art. 5\%, VI, $82^{\circ}$ ). Tanto esse diploma legal, a Lei Orgânica do Ministério Público da Uniăo, quanto a Lei Orgânica do Ministério Público dos Estados (Lei n. ${ }^{\circ}$ 8.625/93), vistos do ponto de vista sistemático, preocupam-se com a ampliação da tutela dos interesses considerados prioritários, deixando às leis setoriais a forma processual de atuaçăo.

Imbuido dessa ratio, expressa na Constituição e nas Leis Orgânicas, e que o legislador do Código de Defesa do Consumidor, em seu art. 113, que acrescentou os $\$ \xi 5^{\circ}$ e $6^{\circ}$ a Lei n. $7.347 / 85$, previu a ação conjunta dos diversos ramos do Ministério Público sempre que os interesses protegidos, por se imbricarem no âmbito de atuação de cada um deles, justificarem tal expediente. É a hipótese frequente e corriqueira de danos ao meio ambiente que afetam a mais de um Estado da Federação ou que atingem bens públicos federais e estaduais. É o caso, ainda, das lesōes ao patrimônio público que atinjam simultaneamente o erário federal e estadual. Basta pensar nos financiamentos de obras públicas pelo govemo estadual e federal.

Poder-se-ia objetar, com alguns processualistas, que na verdade tais hipóteses, no rigor dos termos, não expressariam litisconsórcio, mas uma dupla representação, ou superfetação, tratando-se de entidade única, não já de duas partes que se associam. A objeção, todavia, não guarda consequências práticas, já que a eventual atecnia não exclui a atuação conjunta pretendida pelo legislador.

A verdade é que, em todos os casos acima exemplificados, poderia o legislador, mercê da reserva legal antes aludida (art. $128, \S 5^{\circ}$ ), ter prelerido um sistema de atribuição exclusiva. Não o quis e não o fez, entretanto, para evitar que os interesses constitucionalmente protegidos acabassem por restar indelesos. Preleriu o legislador complementar, portanto, deliberada, ostensiva e enfaticamente, sobrepor atribuiçōes e invocar a atuação conjunta, sempre que o interesse fosse comum entre dois ramos do Ministério Público, justamente para intensificar a tutela de tais interesses, prioritários na tábua de valores constitucional. 
Não é por acaso, destarte, que o art. $5^{\circ}, \S 5^{\circ}$, da Lei n. ${ }^{\circ} 7.347 / 85$ admite o litisconsórcio entre os diversos ramos do Ministério Público. E nem se diga, como pretenderam alguns, que tal preceito não se encontre formalmente em vigor - a menos que se quisesse proceder a inusitada ecdótica dos diários oliciais, homenageando a pretensa mens legislatoris em detrimento da mens legis ${ }^{25}$.

O Código de Defesa do Consumidor, em seu ant. 113, acrescentou o mencionado dispositivo à disciplina da ação civil pública, exatamente porque vishumbrou, nas relaçoes de consumo, a hipótese de interesses soprepostos e o risco de se constituir uma espécie de zona cinzenta, a chamada "terta de ninguém" entre a esfera estadual e federal, que suscitasse o desamparo dos valores constitucionalmente tutelados.

Ressaltou-se, justamente, em doutrina, a importância da atuaçāo litisconsorcial, afastando-se qualquer vício de inconstitucionalidade e salientando-se a sua conveniência em hipóteses peculiares, como foi o caso do leite europeu contaminado pelo acidente nuclear de Chemobyl, verdadeiro leading case que propiciou o litisconsórcio do Ministério Público Federal e do Ministério Público do Estado de São Paulo ${ }^{26}$. No mesmo diapasão, poder-se-iam contabilizar centenas de ações judiciais, em todo o Brasil, bem aceitas pelo Judiciário, em que ambos os ramos do Ministério Público se associam na defesa de interesses coletivos, reforçando, de maneira notável, as possibilidades de êxito. Ressalte-se, a título ilustrativo, a ação civil pública proposta recentemente no Distrito Federal contra atos lesivos ao patrimônio público, no financiamento das obras do metrô de Brasília. O Ministério Público, litisconsorciado, obteve liminar, graças a qual se paralisaram as obras e se redefiniram inteiramente as cláusulas dos contratos

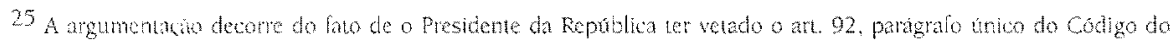

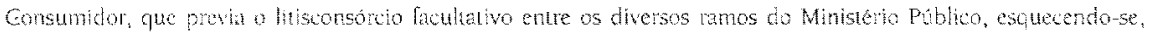

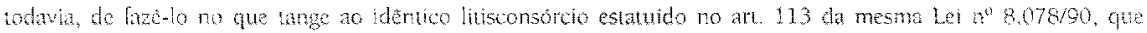

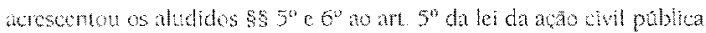

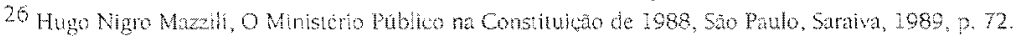


de linanciamento (note-se que as contestaçoes sequer cogitaram da autofágica tese da inconstitucionalidade) $)^{27}$.

Sublinhe-se, entretanto, não ser apenas nas relações de consumo, nas lesöes ao meio ambiente e nas numerosas hipoteses alcançadas pela lei da ação civil pública que a atuação do Ministério Público poderá se fazer conjunta. A Lei n. ${ }^{\circ}$.069, de 13.7.90, o chamado Estatuto da Criança e do Adolescente, em seu art. $210, \$ 1 \%$, também é taxativo: "Admitir-se-á litisconsorcio lacultativo entre os Ministérios Públicos da União e dos Estados na delesa dos interesses e direitos de que cuida esta lei".

- dispositivo, recebido com aplausos pela unanimidade dos especialistas, empresta efetividade à tutela da infância e juventude, evitandose, também aqui, que os processualistas pudessem deixar ao desabrigo as crianças e adolescentes, no afã de definir a competência jurisdicional, sendo mesmo assustadora a possibilidade de classificá-los, para eleito de tutela, em infantes federais e infantes estaduais.

Na esteira de tal atuaçăo conjunta, que se prolifera, repita-se a exaustão, cm todas as Regióes do Brasil pelo órgãos do parquet responsáveis pela delesa dos interesses difusos e coletivos, o Ministério Público Federal celebrou dois convênios de cooperação técnico-juridica com os Ministerios Públicos Estaduais, firmados, o primeiro deles, mediante instrumentos individuais com cada Estado, pelo então Procurador-Geral da República, Dr. Aristides Junqueira de Alvarenga, e o outro, de recente, em instrumento único pelo Procurador-Geral da República, Dr. Geraldo Brindeiro ${ }^{28}$.

Note-se, neste passo, sendo consentido indispensável parêntese, que a atuaçăo conjunta, em sendo matéria ateta às atribuicóes do Ministério Público e, portanto, reservada pela Constituiçào à Lei Complementar, que a

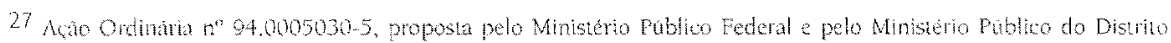

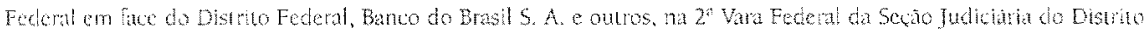
Fectat.

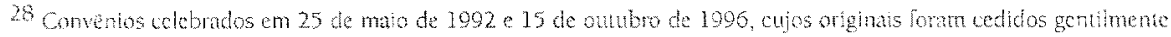

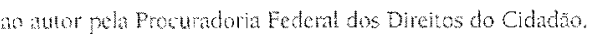


absorveu, resolve-se em questão administrativa, interna corporis, nada afetando ao sistema constitucional. E do ponto administrativo, são os Procuradores-Gerais da República e dos Estados quem, mediante convênio, estabelecem tal atuação.

Leia-se na cláusula terceira do primeiro dos convênios mencionados que a atuação dará prioridade ao "sistema de cooperação visando a possibilitar a atuação conjunta dos conveniados em açoes judiciais nos termos do $\$ 1^{\circ}$ do art. 210 do Estatuto da Criança e do Adolescente". No segundo instrumento é previsto, em sua cláusula terceira, o planejamento para atuação ampla, judicial e extrajudicial, ressaltando-se "a instauraçăo conjunta de procedimentos administrativos, inquéritos civis, e outras medidas judiciais" (original não grifado).

Ora, se o Procurador-Geral da República e os Procuradores Gerais de Justiça, autonidades principais na provocação do controle direto de constitucionalidacle, não somente deixam de cogitar de inconstitucionalidade na espécie como também determinam, expressa, direta e inequivocamente, que todos os órgãos do parquet se envolvam nesta atividade, chega a ser incrivel a resistência de alguns à boa aplicação da lei complementar, não fosse por uma imagem que se tem do Ministério Público inserido no contexto pré-constitucional. $O$ inconformismo poder-se-ia resolver no âmbito interno, quem sabe junto aos diversos Conselhos Superiores do Ministerio Público ou a Câmara de Revisảo do Ministério Público Federal (arts. 58 e segs., Lei Complementar n. 75/93), näo já no ambito do Judiciário, refreando o andamento de importantes ações civis públicas propostas por outros colegas.

Daqui a conchusäo inafastável segundo a qual a atuaçäo conjunta do Ministério Público Federal e Estadual se justifica legal e constitucionalmente, sendo opção de política legislativa em favor da melhor tutela de interesses prioritários.

Resta saber se este sistema processual que, como se viu, atende ao desenho constitucional de um Ministério Público ativo, autónomo e dinâmico, esbarraria de alguma forma no principio do federalismo, a reclama: implicitamente (já que nada ha de expresso a este respeito), que se estremasse a atuação do Ministério Público da União e dos Estados. 
A resposta, também aqui, é categoricamente negativa. No momento em que ate o conceito de soberania nacional tem sido revisto, com a formaçäo dos blocos intemacionais e a globalizaçäo, näo se pode conceber uma noção de federalismo que excluísse a atuaça conjunta dos Estados, a competência concorrente do legislador, a realização de convenios, pelo Executivo, para a cobrança de tributos, para o atendimento médico, para a realizaça da mais variada gama de servicos públicos assim como, no caso concreto, a parceria na fiscalização da lei e na tutela de valores comuns à Federaça e aos Estados.

Tal é o conceito de Federação insculpido no Texto Maior, seguido por centenas de leis, decretos, portarias e atos regulamentares concernentes aos tres Poderes e que atinge a todas as atividades públicas. Näo há qualquer fundamento, portanto, do ponto de vista do sistema federativo, para que se pudesse sustentar que à Federação ofenderia a previsão legal de atuação do Ministério Público Estadual nas Varas Federais ou de litisconsórcio entre dois ramos do parquet.

Ao propósito, convém registrar a página clássica do federalismo brasileiro, escrita nos anos sessenta mas ainda hoje de grande atualidade, onde se adverte, de maneira eloquiente:

"A evoluça demonstra que a federaçäo experimentou um processo de mudança. A concepção clássica, dualista e centrifuga, acabou sendo substituida pela federação moderna, fundada na cooperação e na intensidade das relaços intergovemamentais. A relação entre federalismo e cooperação já se encontra na etimologia da palavra federal, que deriva de foedus: pacto, ajuste, convenção, tratado, e essa raiz entra na composição de laços de amizade, foedus amicitiae, ou de união matrimonial, foedus thalami. Em termos de prospectiva, é razoável presumir que a evolução prosseguirà na linha do desenvolvimento e da consolidação do federalismo cooperativo para modernizar a estrutura do Estado federal ${ }^{n 20}$.

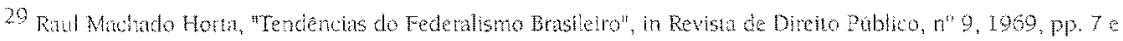
segre, espociatmene, pl, 20 e segs.
} 
Não há que estremar, pois, a lederaçăo da cooperação, mecanismo indispensável ao rederalismo contemporâneo, previsto pelo constituinte e praticado pelo Executivo, Legislativo e atê mesmo pelo Judiciário (bastaria lembrar o empréstimo de jurisdicáo de que trata o art. $109,83^{\circ}, \mathrm{CF}$ ). No caso do Ministério Público, o expediente resulta de convênios nacionais, além de responder a imperativos legais e constitucionais, configurando nútida atribuição concorrente, na medida em que possibilita a tutela mais ampla possivel de interesses comuns, perseguidos ora pelos Ministérios Públicos dos Estados, ora pelo Ministerio Público da União, ora por ambos.

\section{d) O local do dano e a competência funcional-territorial para a propositura da açäo. A Sümula n. 183 do ST\}}

Tem-se disputado, também de maneira intensa, a interpretação a ser dada ao art. $2^{\circ}$ da Lei n. $7.347 / 85$, segundo o qual as açoes civis públicas "serāo propostas no foro do local onde ocorrer o dano, cujo juízo terá competència funcional para processar e julgar a causa". A polêmica surge, frequentemente, em matéria de dano ambiental, quando a lesão se dá em município que não seja sede de Vara Federal. Interroga-se, neste caso, será competente a Seção da Justiça Federal com jurisdição naquela região ou se, ao contrario, o juizo de direito da comarca onde ocorreu o dano é que será o competente, nos termos do art. $109 \& 3^{\circ}$, da Constituição Federal ${ }^{30}$. Este úlimo entendimento acabou por prevalecer no seio do Superior Tribunal de Justiça, que emanou, após sucessivos embargos de divergência, a Súmula n. ${ }^{\circ}$ 183, nos seguintes termos:

"Compete ao juiz estadual, nas comarcas que näo sejam sede de Vara da Justiça Federal, processar e julgar açăo civil pública, ainda que a Uniăo figure no processo".

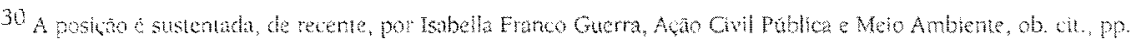
46 e segs.
} 
A questão, todavia, não parece estar definitivamente resolvida, sendo objeto do Recurso Extraordinário n. ${ }^{\circ}$ 161.4510, Relator Min. Moreira Alves, a ser julgado pelo Supremo Tribunal Federal. Com efeito, segundo o entendimento sumulado, $o$ art. $2^{\circ}$ da Lei ${ }^{\circ}{ }^{\circ} 7.247 / 85$ inclui-se entre as exceçóes à competência da Justiça Federal previstas no mencionado $\$ 3^{\circ}$ do art. 109, CF, sendo o Tribunal Regional Federal a instancia recursal competente, a teor do $\$ 4^{\circ}$ do mesmo artigo.

Entretanto, cuidando-se de matéria concernente à competência federal em cujo âmbito a Lei Maior concede uma espécie de empréstimo de jurisdição à Justiça Estadual, a reserva legal para novas hipóteses depende de lei expressa (com motivação vinculada à preocupação constitucional de assegurar o acesso à Justiça no domicílio do demandante), não sendo de se interpretar a simples referencia legal à justiça local como uma lixação excepcional de competência. O constituinte, repita-se anda uma vez, em favor da eletividade do acesso à justiça, concede ao juiz estadual jurisdição leceral em hipóteses absolutamente excepcionais, em razäo da peculiaridade da matéria previdenciária e acidentária.

A possibilidade de criação legal de novas hipoteses näo pode significar, sob pena de ruptura de todo o sistema, que qualquer previsăo normativa de competencia territorial viesse a suplantar as demais previsoes constitucionais de competência funcional em razão da pessoa - ratione personae -, como é o caso do disposto no mesmo art. $109, \& 1^{\circ}$, acerca da Uniăo Federal.

O art. $2^{\circ}$ da Lei n. $7.347 / 85$ limitou-se a preferir o foro do local do dano em detrimento do foro de domicilio do réu. Não pretendeu, à evidencia, com isso, derrogar a competência funcional estabelecida pela Constituição em razão da presença, na relação processual, da União Federal que, segundo quis o constituinte, fixa a competência dos juízes federais de determinada seção judiciária.

Nem se diga, invocando argumento concernente à politica legislativa, que a Justiça estadual teria a seu favor a maior proximidade entre o juizo e o local do dano, facilitando, assim, a instrução processual. Em primeiro 
lugar, tal distância não é necessariamente menor da que separa o referido local do dano e a sede da Justiça Federal mais próxima, situada embora em. outra comarca. Em seguida, é de se convir que certos conflitos coletivos muitas vezes podem ser melhor julgados pela Justiça Federal justamente por um certo distanciamento deste juizo com a realidade local, esta tantas vezes capaz de obstruir a imparcialidade do juiz titular da comarca em cuja circunscriça se verifica o ato lesivo.

Em resumo, embora o art. $109, \S 3^{\circ}$, da Constituição Federal autorize a outorga de jurisdição federal ao juiz de direito, o expediente, para além de excepcional, depende de regulamentação legal expressa e informada pela mesma ratio constitucional, não sendo consentido derrogar a competència funcional da Justiça Federal para as açoes em que figure como autor ou réu a União Federal todas as vezes em que o legislador ordinário previr hipótese de competência luncional em razão do local do evento danoso.

De toda sorte, ainda que näo se concordasse com os argumentos acima despendidos, com o advento do Código do Consumidor parece indiscutivel que o legislador tenha pretendido resguardar, de forma expressa, as hipóteses de competência luncional atribuidas pelo Texto Maior à Jurisdição Federal, na fixação legal de competência - mesmo funcional - em razão do local do dano.

Basta examinar a Lei no 8.078/90, o Código de Defesa do Consumidor:

"Art. 93. Ressalvada a competencia da justiça federal, é competente para a causa a justiça local:

I - no foro do local onde ocorreu o dano, quando de âmbito local;

Il - no foro da Capial do Estado ou o Distrito Federal, para os danos de âmbito nacional ou regional, aplicando-se as regras do Codigo de Processo Civil aos casos de competència concorrente".

Diante da reforma legislativa, vários julgados alteraram o seu ponto de vista, valendo conferir, no âmbito do Tribunal Regional Federal da 1ª Região:

"Processo Civil - Competência - Ação Civil Pública. 
1. A controvérsia gerada, quanto à competẽncia da Justiça Federal nas ações civis públicas intentadas em proteção a patrimônio nacional, ficou superada pelo art. 93, da Lei n. 8.078790 - Código de Defesa do Consumidor.

2. A competência funcional estabelecida no art. $2^{\circ}$, da Lei da Ação Civil Pública - Lei n. 7.347/85-, foi alterada pela lei nova que ressalvou a competencia da Justiça Federal, em qualquer situação"31.

E ainda:

"Processo Civil - Ação Civil Pública

- Lei n. ${ }^{\circ} 7.347 / 85$, art. $2^{\circ}$ - Competència.

1. A competência para a ação civil pública é do juizo do local onde ocorreu o dano, ressalvada a competência da Justiça Federal, nos termos do art. 109 , I, da CF/88 Gurisprudencia divergente - por maioria, AG n. 91.01.13437-0-MG-TRF 1 Reg; AG n. 51132-RJ-TFR. Doutrina favorável: Hely Lopes Meirelles, Hugo Nigro Mazzili, Paulo Roberto de Gouvêa Medina e outros) $)^{1132}$.

O Prof. Carreira Alvim, que hoje integra a $4^{a}$ Turma do Tribunal Regional Federal da $2^{a}$ Região, quando titular da $19^{a}$ Vara Federal do Rio de Janeiro, teve ocasião de decidir, com a erudiçăo e a elegância de estilo que o caracterizam, hipótese que versava sobre a lesão ao meio ambiente ocorrida em municipio desprovido de Vara Federal, destacando-se em suas conclusões:

"A referência a 'competência funcional', constante do art. $2^{\circ}$ da Lei $n$. . $7.347 / 85$ não autoriza a exegese que dele se tem extraido, de que a competencia, em qualquer caso, deve ser atribuida ao juizo estadual local.

A competência funcional, determinada pela natureza especial da funça e pelas exigencias especiais que o juiz é chamado a exercer num dado

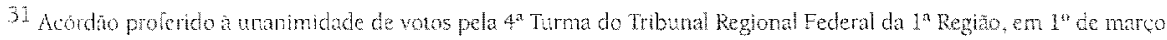
de 1993, no Agravo de Inslrumento n' 93.01.02093-9-BA, sendo Relatora a fuiza Eliana Calmon.

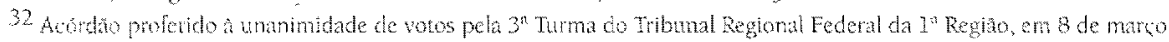
de 1993, no Agravo de insirumento n 93.01.02092-17-BA, sendo relator o Juiz Tourinho Neto. 
processo pode entrelaçar-se com o elemento territorial, dando ensejo à competência territorial-funcional, de caráter absoluto.

A competência funcional da Justiça Federal é informada pela qualidade das pessoas, sobrepujando todas as demais, mesmo que orientadas por criterios de funcionalidade ou em razão da matéria (cf. Emani Fídélis dos Santos).

A referência ao juizo do local do dano (art. $2^{\circ}$ da Lei n. ${ }^{\circ} 7.347 / 85$ ) não significa 'ponto geográfico estrategicamente localizado', porquanto pode ter conotação nacional, regional ou municipal (local), conforme a natureza e extensão do dano que se pretende prevenir ou reparar e o titular do direito lesionado(..)

A qualidade do Ministério Público Federal, de parte no processo, como autor da ação civil pública, determina a competência do foro e juizos federais, em sintonia com o critério funcional, nos contornos fornecidos pela mais moderna doutrina. O Ministerio Público Federal insere-se, por compreensäo analógica, no contexto do art. 109 , I, da CF, do mesmo modo que as lundaçöes federais, embora näo referidos expressamente.

$\mathrm{O}$ art. $2^{\circ}$ da Lei n. ${ }^{\circ} 7.347 / 85$ não cuidou da competencia de foro em razāo do 'domicilio da parte'- que era a fronteira, o limite até onde poderia ir a atividade integrativa ordinária, autorizada pelo art. 126 da EC n. $1 / 69$, à luz do qual essa lei foi promulgada - pelo que não se há que falar em 'compatibilidade' ou 'recepção' a luz do art. $109, \S 3^{\circ}$, por não ser a hipótese ${ }^{133}$.

O Superior Tribunal de Justiça, na respeitável unificação jurisprudencial, não considerou o Código de Defesa do Consumidor, cuja incidência nas açōes civis públicas, como acima já visto, decorre de determinação expressa do art. 117, que acrescentou o art. 21 à Lei n." 7.347/85: "aplicam-se à defesa dos direitos e interesses difusos, coletivos e individuais, no que for cabivel, os dispositivos do Título III da lei que institui o Código de Delesa do Consumidor".

33 Original gentilmente sedto pelo attor. 
Considerando-se tais circunstâncias, a matéria, embora sumulada, parece ainda sujeita a tratamento diverso, seja por parte do próprio supenior Tribunal, em hutura reconsideração, seja por obra do Supremo Tribunal. É aguardar-se.

\section{BIBLIOGRAFIA}

BOBb10. Norberto, Dala strutura alla funzione. Nuovi studi di teoria del dinito, 2" ed., Milano, Edizoni di Comunita: 1084, (12 ed. 1977).

CARNIIRO, Paulo Gezar Pinhero, O Ministerio Público no Processo Civil e Fend, Rio de Janciro, Forcuse, 5 al, 1905 , pp. 23 e segs.

CARVAlIO fulHo, José dos Santos, Acáo Civil Pública - Comentatos por artigo, Rio de Janeiro, Freitas Bestos, 1095, prp. 54 c segs.

DI PIETRo, Maria Sylva, Direito Administrativo, Sa Panlo, Atlas, 1991. p. 466; Raquel Elas Ferrein, Acto Civil Pública: do Ministrio Público e da Eficacia da Liminar, in Seleços Jurdicas ADV COAD. n* $02190,23.23$

FONSECA, Amoldo Vedeiros da, Caso Fortuto e Teoria da Imprevisao, Rio de Janem, Imprensa Nacional. $2^{4}$ d. 1943, pp. 193 e segs.

Tranciso Samporo, Responsabildade Civil e Reparaso de Danos ao Meio Anbiene, no prolo da Editora Lumen lurs (original codido gentimente pelo autor)

GUmRa, Isablla Frneo, Acano Cvil Pública e Meio Ambiente, Rio de Janeiro, Forense 1997, pp. 65 e segs.

MARX, Kan \& Frietrich Engels. Manfesto del parto comungta (1848), trad. italiana di F Toglatt, Tiditori Rumit, Roma, $2983,2^{*}$ ed., p. 96.

MAZZLL, Hugo Nigro, O Ministerio Público na Constitucho de 1988, Săo Paulo, Sarava, 1989, p. 72.

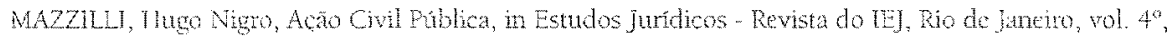
3. 95 .

Mello, leloisa Capena Vicira de, "A Tutela dos mteresses Individuais Homogeneos dos Consumidores e a Micsta da Legitmidade do Ministerio Publico", original no prein da Revistu de Direito Renovar, cediclo gentilmente pola antora.

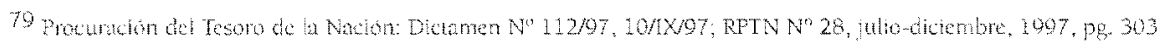
lel subrayado nos pertenecel. 
Natalino Irti, L'eta della decodificazione, Milano, Giuffrê, 1976, pp. 9 e segs.

SAMPAO, Francisco, Meio Ambiente no Direlto Brasileiro Atual, Curtiba, jurua, 1993. p. 23.

SIVA, Jose Afonso, Direito Ubanistico Brasileiro, São Raulo, Ed. Revista dos Tribunais, 1981, p. 435

TEPEDINO, Gusavo, Contomos Constimcionais da Propriedade Frivada, in Estudos em Homenagem ao Prol. Cato Táto (org. Carlos Alberro Menezes Direito), Rio de Janeiro, Ed. Renovar, 1997, pp. 309 e segs WATANABE, Kazuo, Comentários ao art 81 da Let $n^{\circ} 8.07890$, in Codigo Brasileiro de Defesa do Consumicior, Rio do Janciro, Forense Universitaria, 1991, p. 511

WATANABE, Kazuo, Denandas Coletivas e Problemas Emergentes da Praxis Forense, in As Garantias do Cidadão ma Justica Coord. Sálvio de Figueiredo, Saraiva, 1993, pp. 118 e segs.

ZAVASCKI, Toon Albino, "O Ministerio Publico e a Defesa de Direitos Individuais Homogeneos", in Rev. Inf. Legislutia, $x^{\circ} 117$, p. 185 , original năo grifado. 